\title{
LEGAL CERTAINTY IN THE EASE OF EFFORT IN THE ERA OF INDUSTRIAL REVOLUTION 4.0 RELATED TO NOTARY PROFESSION
}

\author{
Fadhil Yazid \\ Faculty of Law, University of Dharmawangsa \\ fadhilyzd16@gmail.com
}

ABSTRACT

The start of the 4.0 Industrial Revolution brought many changes to the world. This is the era in which the practice of automation and data exchange, as well as the use of Internet technology, cloud computing, and cognitive computing will colorize various sectors of human life, including the realm of profession. All changes, definitely brings two things: challenges and opportunities. Very wise if we can understand the changes that occurred through the Industrial Revolution of 4.0 and what is the impact for professions, practitioners and officials in the field of law. For a notary, it is time to look at the impact of the 4.0 Industrial Revolution as a challenge and opportunity for future sustainability of the profession. As known, the legal system is divided into two main systems namely common law and civil law, and a small part of the system of religious and mixed law. On both the legal system, the position and authority of the notary is different. A civil law or Latin notary Notary is an official with the authority given by the State to create and issue an authentic deed as well as to provide clarification or legal counseling to the parties concerned. Whereas, the common Law Notary Authority is accepting, noting statements, knowing signatures, certifying copies, all of which are used to support the administrative of other legal proceedings, and not an authentic deed by itself. .

Keywords: Legal Certainty, Industrial 4.0, Notary.

\section{Journal History}

Received

August 13, 2020;

Reviewed

Accepted

October 15, 2020;

Published

: October 29, 2020;

: November 1, 2020

Copyright @2020 NLR. All right reserved. 


\section{INTRODUCTION}

Notarized pursuant to article 1 number 1 of the Republic of Indonesia Act No. 2 of year 2014 of amendment to number 30 year 2004 concerning notary Department (UUJN) stated that notary is a general official authorised to make an authentic deed and has other authority as referred to in this Act or under other laws.

In the era of the 4.0 industrial Revolution, no profession had been touched by the impact of digitisation including the notary profession. The notary should be prepared for the look and change demands ranging from the company and the registration procedure that shifts to electronic format and online transmission. Technological advances from the last two decades have had a major impact on how notarized transactions and interacting with public authorities, state agencies. The concept of innovation questioned the role of notary in an almost fully digital business environment.

With regards to the development of digitisation, then any innovation that is part of a digital hype cycle is required a conscious reflection to question whether a transaction without a trusted thirdparty assistance really more guarantees legal certainty and consumer protection. Whether the advancement in the field of information technology can affect the notary function in carrying out his profession will influence the office of the Notary (civil law) in anticipation of the challenges faced and has changed the ease of effort in the era of the 4.0 Industrial Revolution.

Revolution 4.0. With its digital advancement and the presence of artificial intelligence machines and big data, it has changed the paradigm and the way people in law have become "alarms" for disruption to the legal profession, especially notaries, who were previously untouched. Like the business world, in the era of disruption, technology crushes anyone who is not innovative and efficient, including the notary profession which has become the business industry.

The notary profession is a very important profession for the development of the investment climate in Indonesia. Therefore, integrity and professionalism of a notary are indispensable for the success of the Industrial 4.0 era. In addition, in terms of business needs, speed and accuracy is an urgency that must be considered. However, the authenticity of a notarial deed must be maintained.

\section{METHOD}

The method of research in this writing is normative juridical by analyzing the legal material in the form of Law No. 2 of 2014 on the notary Department through Library studies. 


\section{DISCUSSION}

\section{The Existence Of Civil Law Notary In Era 4.0}

Notary comes from the word notarius, which in the 2nd and 3rd century $\mathrm{AD}$, notary was known as the class of people who recorded speeches. The profession, which is one of the oldest legal professions in the world, continues to develop.

Based on the origin of notarial institutions, notaries are divided into two types, namely civil law notaries who come from Northern Italy and common law notaries who come from England and Scandinavia. As for what is characteristic of a civil law notary is being appointed by the competent authority whose aim is to serve the interests of the general public and to receive an honorarium from the general public. ${ }^{1}$

Meanwhile, common law notaries are not appointed by the ruling official. For example in England, a notary is appointed by the bishop of the church or his proxies so that according to Meyer, the notary common law deed is not an authentic deed. In addition, deeds made by civil law notaries have more power, namely validating that the facts written in them are true and cannot be challenged by the parties. ${ }^{2}$

Common law notary deeds cannot be accepted directly by the court as evidence of written facts. Common law courts also place more importance on seals or stamps and

${ }^{1}$ Herlien Budiono, Kumpulan Tulisan Hukum Perdata di Bidang Kenotariatan, (Bandung: PT Citra Aditya Bakti, 2008), p. 21 witnesses who can confirm that the contents of the deed are true according to the wishes of the parties. The common law notary also has no role in the establishment of legal entities, making agreements, drawing up deeds of separation and distribution of inheritance. Common law notaries usually only play a role in making power of attorney and protest drafts.

Currently, the definition of a notary is clearly contained in Article 1 number 1 of Law number 2 of 2014 amendments to Law Number 30 of 2004 concerning the Position of a Notary, which states that a notary is a public official who has the authority to make authentic deeds and other powers as referred to in this law.

As a public official, a notary is not a public official or state administration official and does not receive a salary from the state, even though he is given the authority to use the Garuda symbol. The position of the notary is maintained so that it can be neutral in providing legal education and can take legal actions that will not cause problems in the future, both for clients and other parties.

Notary's authority can be seen in Article 15 of the Law on notary office. The notary has the authority to make authentic Deeds regarding all actions, agreements, and stipulations required by the laws and regulations and / or that the interested party wants

2 Tan Thong Kie, Studi Notariat \& Serba Serbi Praktek Notaris, (Jakarta : PT. Ichtiar Baru Van Hoeve, 2000), p. 32 
to be stated in the authentic Deed, guarantees the certainty of the date of making the deed, keeps the deed, provides grosse, copies and excerpts of the deed, all of this as long as the making of the Deed is not assigned or excluded to other officials or other people as stipulated by law.

In addition, the Notary is also authorized:

1) Ratify the signature and determine the certainty of the date of the letter under the hand by registering in a special book (legalization);

2) To record letters under hand by registering in a special book;

3) Make a copy of the original letter under hand in the form of a copy containing the description as written and described in the letter concerned;

4) Validating the compatibility of the photocopy with the original letter;

5) Provide legal counseling in connection with making deeds;

6) Make deeds related to land; or

7) Make a deed of auction minutes.

The role of a notary is very important in ensuring legal certainty and protection, especially in the economic and industrial fields.
The 4.0 Industrial revolution has impacted changes in the world of industry or working world including the legal profession of one of them notary. The development of science and technology should be addressed carefully and wisely by the notary, for example in the Industrial Revolution 4.0 that can help acceleration and ease in the field of administration, archiving and transmission of data. ${ }^{3}$

In the Industrial Revolution 4.0 computers and robots were used as the basis for which now connected to the Internet in a shared network. The initial part in the 4.0 Industrial Revolution was the "Internet of Things". Computers are getting smaller and increasingly sophisticated and smartphones allow people to connect with the outside world.

The second part is the advancement of technology that then creates all the new ways of censorship and all the ways to utilize the information generated from those sensors and record it for 24 hours. Arguably a new phenomenon is almost a loss of personal life (privacy) because of all movements or activities people can monitor in the control center.

The third part of the 4.0 Industrial Revolution is that Cloud Computing is a computer that can do complex calculations. The fourth and greatest part is Machine Learning, which is a machine capable of learning, consciously making

Kehidupan Masyarakat, (Semarang : CV.AGUNG, 2019), p. 5 
mistakes and doing proper correction in order to improve the next result. ${ }^{4}$

From the development of the Industrial revolution has been attempted to follow the development of digitisation and utilize it for the beta world. Some professions, practitioners and notary in the field of continental law have conducted monthly routine reports conducted digitally. Although there are still limited utilization in the field of Notariatan but at least raises the question of whether the later supercomputer will be able to replace human abilities.

For a notary, it is time to view the impact of the Industrial Revolution 4.0 as a challenge and opportunity for the sustainability of the profession in the future.

Notaries, in exercising their authority and obligations, are required to play a role in ensuring legal certainty, legal order, and legal protection which is based on truth and justice. The position of a Notary is also closely related to his authority in carrying out certain positions as a profession in legal services.

In terms of legal certainty of the ease of effort in the era of the 4.0 industrial Revolution related to the notary profession, there are some things to be examined. I.e: ${ }^{5}$

1. In order for business actors to run their company to start trying to need some things that can not be avoided, namely

${ }^{4}$ Dikdik M. Arief Mansur dan Elisaris Gultom, Cyber Law dan Aspek Hukum Teknologi Informal, (Bandung : Refika Aditama, 2015), p. 46. needed capital, skills in the field to be executed and completeness of formil form a form of business entity. In Indonesia is known as a form of business entity, which is legal entity and not legal entity. The deed of establishment for a certain form of business required assistance from the notary public including assistance for the approval as a legal entity to the government, while for companies that are not legal entity with sufficient registration on the relevant agencies. In addition to the determination of the form of business entity, there is a completeness of permits permits and other letters. After the procedure, the business can start working legally. The challenges that entrepreneurs face are speed, timeliness, and legal certainty in the selfequipping and cost-effective that will be the opportunity to be able to compete properly and properly.

2. The authentic deed made by the notary has an outward proof power, the strength of the evidence of formyl and material so that it can be the strongest and most fully

5 Aris Yulia, Profesi Notaris di Era Industrialisasi dalam Perspektif Transendensi Pancasila, Jurnal Law \& Justice, Volume 4, Nomor 1, 2019, p. 6 
proven instrument. The strength of notarial deed that guarantees legal certainty will be faced with the challenge of digitization relating to the use of supercomputers in the era of the 4.0 Industrial Revolution. The study needs to be done to the extent that the notary authority and process or part of the process of making notarial deed using the computer/Internet network still has the characteristics of authentic deed and the strength of perfect proof.

3. Cybernotary. As with technological advances, legislation is expected to provide facilities to a new paradigm along with advances in the field of information technology. This evolution is especially important with regards to electronic communication in the field of trade including correspondence via electronic (e-mail). The World Wide Web and Electronic Data Interchange (EDI) have successfully managed to support communication especially among businesses who originally communicated by conventional writing. Provision of article 15 paragraph (3) UUJN mentions that another authority of a notary is to certify transactions conducted electronically even if not further explained whether the intended is the same as cybernotary. At least the intended electronic documents. Last there has been regulation of the Minister of Communications and Informatics of the Republic of Indonesia Number 11 year 2018 on electronic certification implementation.

4. Online Trading has been conducted in the activities of stock exchanges and business retail. Electronic transactions have also been known in the world of notary, namely the administrative system of the legal entity (SABH) relating to the application to obtain the decision on the ratification of legal entities of limited liability (PT) through the Ministry of Justice and Human rights electronically. The notary participated in taking new roles and responsibilities, for example by supporting authorities in detecting and handling money laundering cases. The notary obligation to report it to the Financial Transaction Reporting Center (PPATK) through the application on line or referred to as the Gathering Reports \& Information Processing System (GRIPS) with the obligation to the 
notary to register to the https://grips.ppatk.go.id site, relating to the suspicion of criminal acts of money laundering and criminal acts of terrorism including the principle of recognizing the benefit owner of the corporation relating to the crime In terms of acceleration and increased investment and strive (law number 25 year 2007 on Investment), the Government of the Republic of Indonesia has implemented an electronically integrated licensing service called the Online Single Submission (OSS). Including the facilities provided to business actors in carrying out the business and/or activities provided in a form of approval that is poured in the form of letter/approval or fulfillment of the terms and/or commitments.

5. In the manufacture of authentic electronic deed must be thoroughly careful and thorough in the making, because the electronic deed has a weakness in the evidence, because the deed is virtual is very vulnerable to be done a change, forged or can be made by the fact of the Party not the parties

6 A.M.Ramli, Kekuatan Akta Elektronik Sebagai Alat Bukti Pada concerned but as if acting and behave like the true party. ${ }^{6}$

Notaries are required to adjust the development of the era of globalization that occurs at this time, this is due to the relationship of data that can occur in transaski conducted in electronic media or transactions conducted online, as well as increasingly developing and integrated with each other, for example is the relationship between the Ministry of Law and Human Rights integrated with the Coordinating Ministry of Economic Affairs, this relationship is integrated through the latest licensing system namely OSS (Online Single Submission) in accordance with Government Regulation No. 24 of 2018.

The current government promotes a policy of facilitating and accelerating the implementation of investment and working procedures in the Republic of Indonesia. The Republic of Indonesia requires a program or system, namely Online Single Submission (OSS), which is an electronic system containing the licensing of attempted issued by OSS institutions for and on behalf of ministers, institutions, governors, or regents/mayors to businesses. OSS Institution is the development of One Door Integrated Service (PTSP).

This OSS system has been built since October 2017 on the mandate of presidential Regulation No. 91 of

Transaksi E-Commerce Dalam Sistem Hukum Indonesia, Media Notariat, April-Juni 2003, Tahun XVIII, p.19. 
2017 on Accelerated Implementation of Trying, with the enactment of OSS system, every business entity or individual who registers a business through OSS will have a Master Number.

OSS System, which is the development of the One Door Integrated Servant system (PTSP), will interconnect and integrate information technology system and communication licensing services by utilizing PTSP. PTSP at the central level is managed by the Electronic Investment Infromation and Licensing Service System (SPIPISE) of the Capital Security Coordinating Agency (BKPM), while PTSP at the regional level uses the Integrated Licensing Service Intelligent Application system for the Public, managed by the Ministry of Communication and Informatics. This system is also supported by the system of various ministries / licensing publishing agencies including the Indonesian National Single Window (INSW) system.

The current era of globalization, licensing management utilizing technological developments and information is something that cannot be avoided by anyone who has had a huge impact in various fields of human life.

The real impact of the development of technology and information can be seen not only in the socio-cultural and economic fields, but also in the field of notary law, which is marked by the existence of a provision that clearly states that a Notary has the authority in the field of
Cyber Notary and registration of business licenses through Online Single Submission.

Legal order, certainty, and protection of the law are imperative in business licensing, especially in realizing Ease of Doing Business. Legal traffic in people's lives requires evidence that will clearly determine the rights and obligations of individuals as legal subjects in society. This is reinforced by the fact that the legal relationship between one legal subject and another is increasingly complex and increasingly global.

Regarding the complexity of the economy, politics and cultural pluralization will force every legal subject to act quickly, precisely and with legal certainty, making the existence of authentic notary deeds a primary need in all spheres related to primary interactions including legal, political, economic, and investment interactions. Therefore, OSS application is required by attaching the deed of establishment made by the Notary at the beginning of the issuance of the Business Identification Number which is the initial milestone in terms of business licensing.

In realizing the Ease of Doing Business, the importance of the function of the Notary's and Notary's deed itself increases, among others in terms of making and amending Foreign Investment and Domestic Investment deeds, deeds must be made first and get approval from the Minister of Law and Human Rights before applying for licenses. effort. In 
addition, notaries need to check investment plans with paid-up capital, especially the Debt Equity Ratio (DER), as well as the need for accuracy and understanding of the Indonesian Negative List. Some of these things become primary support in making and changing business licenses.

\section{The Development Of Notary Roles In Indonesia}

The implementation of the notary public is determined by the legislation relating to duties, authorities and prohibitions in the notary. In addition to the legislation, there is also a notary code of ethics which lays out the moral norms of conduct applied and must be followed by a notary in his profession. With regards to advances in the field of information technology as artificial intelligence or artificial intelligences will continue to develop impact for the notary in the running of office.

The practice and procedure of creating authentic deeds emphasizes on preventive justice that creates and maintains legal certainty in the interest of the community and avoids demands. The influence of information technology advances to notary office in Indonesia will be determined by two factors, namely political law and legal awareness.

The prevailing laws and regulations should not be ruled out, but must be viewed as a tool that must be enabled for the creation and legal certainty of the community. Legislation must be run by political decisions or from legislation that becomes part of legal politics. The state works through its organ of weakness, with tasks and functions to draft legislation to be made.

Thus, governments that are part of the state's institutional capacity are able to give pressure as well as directing the legal system as well as legal politics that should be chosen and developed. Indonesia is a legal state, so politics should follow the law and not vice versa. One indication of what and how political law a country can be found and revealed in the Constitution.

Human beings in order to sustain his life are faced with the necessity of fulfilling the basic needs in regard to body, ratio and feelings. Besides the basic needs, there are also psychic needs, such as the need to advance science, security, legal certainty and justice. Legal awareness reveals oneself in the belief of the truth of the deepest mind. Through the psychic path, recognition of the truthfulness of a rule can be raised, which is demonstrated by the belief of rule-making policy.

If this right is not there, it cannot be said there is a legal consciousness. Acceptance and purification of orders or prohibitions of the ruler is not the same as accepting the truth. The awareness of the law in principle must be realized or implemented by the ruler, who should capture the consciousness as it grows in society and reveal it in the legislation. Forming and making rules must be implemented by guiding the perceived measures so as to lubricated 
the sense of justice in line with the demands of the community.

On all legal systems requiring an authentic form of certain legal acts, the deed has the perfect value and strength of proof. The main mission of the notary is to develop a proof tool with a purpose not only valid but also economic value. A fact, that in determining the correctness of information, identification, proficiency and authority to take legal action intended by the parties can only be obtained and determined by a notary public.

Besides this, advances in technology have been utilized in the world of notary with online registration system such as $\mathrm{SABH}$, OSS and GRIPS that support and accelerate notary to access imformation. Information and communication technology helps quite significantly the speed and quality of service notary. Many protocol-based jobs have been taken over by an information system that makes notary work a cost-effective.

Legal politics and legal awareness will determine the extent to which the influence of progress in the field of information technology will be implemented in the form of legislation.

The use of high-level technology with automation and digitization should provide added value for speed as well as legal certainty to society in line with the demands of community needs.

7 Hikmawanto Juwana, Tantangan Bagi Notaris Indonesia, (Jakarta : Seminar Cyber Notary, , 2011). p.6
Lawmakers with legal politics without ignoring the public law awareness further further digitization progress without changing the nature of the notary public, the ordinance of making notarial deed and the characteristics of authentic deed.

\section{Validity Of Notary Deed That Uses Cyber Notary As An Authentic Deed}

In a 1994 report issued by the Information Security Committee of the American bar Association, the committee described a profession similar to a notary public, but that documents were created and those in those professions were electronically based, which had the function of increasing confidence in the documents. In this sphere, cyber notary has a role to authenticate electronically based documents, which from the authentication of the document can be printed out anywhere and anytime.

Cyber Notary also has a role to provide certainty to parties located in other countries whether when conducting transactions in a country is completely of its own consciousness and without any coercion or threat to sign such electronic-based documents. ${ }^{7}$

There are two aspects to emphasize cyber notary, namely authority and technology. Progress in the economic sector makes the aspects of authority and technology interrelated. Rapid economic changes 
require notaries to immediately process contracts so that one of the means that can support the acceleration of the process is information technology.

Cyber Notary has the main function of certifying and authenticating electronic transaction system. Certification itself has the understanding that the notary has the authority to act as certification authority (trusted third party) so that notaries can issue digital certificates to interested parties. In contrast to the authenticity function related to the legal aspects that must be fulfilled in the implementation of electronic transactions. $^{8}$

Cyber notary has been implemented by notaries such as implementation in the General Meeting of Shareholders of Limited Liability Company which is a type of relaas deed. This is because in the Law of the Limited Liability Company, especially Article 77 of Law No. 40 of 2007 of the Limited Liability Company states that the implementation of the General Meeting of Shareholders can be conducted through teleconference media, video conferences, or other electronic media facilities that allow all participants of the General Meeting of Shareholders to see and hear and directly participate in the meeting.

In addition, the use of computers in the creation of deed and during the process of registration of

8 Agung Fajar Matra, Penerapan Cyber Notary di Indonesia Ditinjau dari Undang-Undang Nomor 30 Tahun 2004 legal entities through the Legal Entity Administration System is a sign that notaries in Indonesia have begun to use computer and internet systems in the application of their duties. The Administrative System of the Legal Entity itself is a computerized system created by the Ministry of Law and Human Rights to conduct a number of transactions including will reporting, registration of legal entities and registration to be appointed as a notary itself.

In contrast to the Partij deed which does not allow it to be done in a cyber notary way. This is because notaries must see and hear directly in the reading and signing made by the parties, witnesses and notaries themselves (Article 16 paragraph (1) letter m law No. 2 of 2014 on notary office).

However, if it is possible to make a partij deed by cyber notary as has been done in the implementation of the General Meeting of Shareholders, the author concludes that at the end of the deed is given a clause that the reading of the deed and its signing is carried out in more than one city or place in accordance with the place of the parties concerned by using electronic devices (teleconference or videocall).

The information or explanation of the parties or the results of the question and answer with the parties and the evidence given to the notary which is then poured into the form of notarial deed is the basic material for

tentang Jabatan Notaris, (Depok : Tesis Magister Kenotariatan FH UI :, 2012), p. 58. 
the structure of the notarial deed. Some things that can be used as the basis for building a notary structure are:

a) The background to be promised;

b) Identification of legal parties Or subjects;

c) Identification of the object to be promised;

d) Formulate a framework of the deed and formulate the substance of the deed containing concerning the position of the parties, the limitations that may and may not be carried out according to the rule of law, the restricted things in its implementation;

e) Legal options and court options, dispute resolution clauses and in relation to other deed (if any). ${ }^{9}$

In connection with the proof of electronic documents to be used as a valid evidence tool, this is stipulated in Article 5 paragraph (1) of Law No. 11 of 2008 on Electronic Information and Transactions.

In connection with other authority granted to notaries that are to certify transactions using cyber notary, then the print out results of the certification can also be categorized into electronic documents. The electronic documents must also comply with the elements in article
1868 of the Civil Code concerning the authenticity of the deed.

The procedure of making notary deed in cyber notary according to the author has the same procedure as the creation of notary deed that has been implemented so far. However, what distinguishes from the two procedures is in terms of facing, where the face here is done in a physically present way but facing in relation to cyber notary is done by using electronic devices, such as teleconference or video call.

The procedure for making notary deed using cyber notary is that the parties present in front of the notary by using a teleconference or video call to convey the intent and purpose of facing the notary and submitting the deed to be made, the parties must show their identity clearly to the notary by sending their identity via electronic device e.g. faximile/email and notary matching the identity with the person in the teleconference or video call, after that, the notary makes the deed in accordance with the form determined by the law which is then read before the parties where in the reading of the deed either notary, witness or the parties use teleconference or video call at the same time, and after completion the deed is read and understood by the parties concerned, the deed is signed by the parties, witnesses and notaries using a digital signature.

9 Habib Adjie, Kebatalan dan Pembatalan Akta Notaris, (Bandung: Refika Aditama, 2011) p. 37. 
Constraints faced by the notary with the existence of an electronic signature to serve as evidence, the electronic document must be declared legally and accurately with the original that already existed. Evidence of electronic documents as evidence in order to have legal force and irrefutable power of proof, must be accompanied and accompanied by evidence of guidance from expert statements.

The authenticity of the electronic signature can be immediately determined or can be immediately known in court. This is due to the existence of an Electronic Certification Operator (Certification Authority), which is an existing infrastructure linkage agency outside the parties that have been granted a license by the government to issue electronic signatures. ${ }^{10}$

So as to prove the signature electronically, it can be concluded that the Electronic Signature has legal force and legal consequences as long as it meets the following requirements:

1) Data on the creation of related electronic signatures only to signers;

2) Electronic signature creation data at the time of electronic signing process is only within the authority of the signer;

10 Arimukti Wibowo dkk, Kerangka Hukum Digital Signature dalam Elektronic Commerce, (Jakarta : seminar Masyarakat Telekomunikasi Indonesia Pusat Ilmu
3) Any changes to electronic signatures that occur after the time of signing may be known;

4) Any changes to electronic information relating to such electronic signature after the time of signing may be known;

5) There is a specific way used to identify who the signer is;

6) There is a certain way to indicate that the signer has consented to the relevant electronic information.

In connection with the main authority of the notary, namely in making deeds, the application of cyber notary, faces several obstacles, namely the obligation for tappers to sign the deed and if the parties are unable to sign, they must state the reason. The Netherlands, where most of our regulations originate, has regulated the existence of electronic signatures and is recognized as being the same as traditional signatures through a rule called richtlijnen electronische handtekeningen or electronic signature instructions. ${ }^{11}$

The trick is to entrust the signature to an independent institution called the Trusted Third Party. Trusted Third Party is in charge of storing digital signatures, ensuring the correctness of data exchange and storing other data using cryptographic

Komputer, Universitas Indonesia, 1999), p.11

11 Niniek Suparni, Cyberspace: Problematika dan Antisipasi Pengaturannya, (Jakarta: Sinar Grafika, 2009), p. 9. 
methods. This institution in the country of Anglo Saxon is known as the escrow source code which is the source code of a computer program which is the key to checking identity, both signatures and other electronic data.

Apart from being constrained by the problem of signing the deed, the making of the notary deed also has problems with regard to the power of proof. The evidentiary strength of the results of electronic evidence can only be accepted as valid evidence by the judge through evidence of guidance and expert testimony.

If you wish to present evidence using electronic means, you must first state that the results obtained are truly authentic, according to what the defendant did. Anything that is produced in the electronic field should be approved and recognized by the competent authority, so that what is produced is in accordance with the original form, even though the original form of evidence cannot be presented.

The expert's statement is a statement from a person who really knows and understands about electronic devices that will be presented at the trial to confirm that the defendant has indeed committed a crime in the field of electronics.

For example, if a judge questions the validity of an Identity Card, then this is where the expert's role is to provide information based on the knowledge he has so that in the end the right to collect opens his thoughts and insights that the original meaning does not have to be the same as the original in the conventional sense. Meanwhile, evidence of guidance should provide instructions to the judge that an error has occurred in the electronic field.

\section{Industrial Revolution Challenge 4.0 Against Notary Professions}

Notaries in the profession are required to adjust and keep up to date in the era of globalization and industrial revolution 4.0, where many business activities and transactions are conducted through integrated data-driven electronic means, such as online Fiduciary systems, and subsequent registration of legal entities online through the Legal Entity Administration System. Integrated Electronic Data System is a means and opportunity to make Notary Work easier, faster, precise and efficient.

In the Digital Age or so-called Digital Disruption Era, Notary with Electronic System or Online can make work easier. The ways that should be prepared by notaries in the face of technological industry advances are:

1) Follow the Rules, because the Rules will continue to change a time. That is, Upgrading the science gained.

2) Following the Media, means what media is currently booming, because the Notary is a Public Official, which is dealing with the Client, so, by following the Media, can be used as a tool to approach through by 
providing solutions what should be given by the Notary to the Client.

3) Able to adapt to the development of information technology in this era 4.0 and able to utilize Artificial Intelligence technology in carrying out its responsibilities as a public official. For example, in the exercise of Electronic Dependent Rights, notary activities are carried out online through ahu.go.id, and others.

4) Has competitiveness at the global level.

5) Develop yourself through skill possessed by improving its quality and Literate information technology.

6) Regulate the terms, obligations, prohibitions, and Notary Code of Conduct.

The challenges of the Industrial Revolution 4.0 in the future are the subject of:

1) Information technology security issues

2) Challenges to the reliability and stability of production machines

3) Challenges on the lack of an adequate skill

4) There is a reluctance to change by stakeholders

5) The challenge of losing many jobs due to automation
Human Resources became a problem that had to be faced in the era of Industrial Revolution 4.0. This is because in addition to needing reliable and superior Human Resources, as well as special skills. In the legal profession such as Notary is required to be able to improve services in the community with maximum utilization of existing information technology.

Notaries can add a broad insight into critical thinking skills and can solve problems, communicate, be creative and be able to collaborate. Industrial Revolution 4.0 problems for Indonesia include:

1) Post truth or post-truth becomes a phenomenon in today's cutting-edge digital world, where the flow of information becomes so fast that the verification process is neglected until finally the truth becomes biased.

2) Ecological damage can be separated from the construction of an industrial area, because one of the indexes of natural damage is caused by land expansion and industrial waste disposal.

3) The logical consequence for industrial society is dehumanization. The humanitarian and socialization side to society will be reduced by the presence of human behavior that is already inhumane, the cultural context that is 
increasingly lost due to economic pressures and the existence of jobs.

The legal profession such as notaries is human beings with special education and expertise that cannot be replaced with robots because they have to think carefully, carefully and fairly, for it is impossible to simply enter data on computers and computers can solve.

The notary profession provides legal services to the community to achieve legal certainty as well with the industrial revolution 4.0 makes the development process increasing then notary services are now one of the legal needs of the community.

\section{Notary Legal Profession Versus Artificial Intelligence}

Knowledge is the basis for the construction of general premises or postulates of science, which in turn will play a role as the "biological mother" of the birth of technology. Technology that was previously seen as "downstream" products produced by humans, is now competing with humans. In a study revealed for the first time in a competition the accuracy rate of artificial intelligence machines is more accurate than human intelligence.

Human ability has become less relevant so that in some cases it is replaced by an algorithm system. It is now necessary to find out why artificial intelligence tools are smarter than the human-run legal profession and whether the role of the legal profession can be replaced by the role of artificial intelligence tools.

Several technological developments, such as digital documents, data processing, chatbots, flexible working, and predictive analytics, have further accelerated disruption in the legal sector. These sophisticated technological tools are programmed to accommodate all legal regulations and jurisprudence, and are even able to provide various legal opinions on various legal issues being asked.

One of the potential victims in this case to the legal profession is the notary profession. For the legal profession, there are strict regulations, such as special requirements to become a notary. People can say that today the intelligence machine is not a competitor for notaries because the law regulates the legality of an agreement requiring a notary deed, for example the establishment of a Limited Liability Company, a fiduciary agreement, and so on.

You can imagine how the notary profession if the future of law does not determine the validity of certain agreements through notarial deeds, then technical legal work such as drafting agreements or contracts will easily be replaced by artificial intelligence machines. Contracting parties, with the help of artificial intelligence machines, can independently compile business contracts in internet applications in front of a computer by simply processing the data input of the terms and conditions of the parties. 
Professional law education relies more on vocational training to produce legal craftsmanship and legal mechanics. The problem is, in the digital era, more sophisticated technology will replace something that is technological as well. This means that legal professions that are mechanical or technologically similar to punishment will be defeated and replaced by artificial intelligence machines.

Artificial intelligence machines work on the basis of the Case Based Reasoning (CBR) program, which is an approach that is programmed to find solutions using references to solutions to previous problems to solve new problems. So, CBR solves a new problem by using a similar solution to the unprecedented problem.

CBR can be likened to transferring a database of cases that an expert already has onto a computer hard drive to be used to solve similar new cases. With artificial intelligence machines, legal service users only need to rely on disks containing billions of gygabites of data, in which millions of simulated cases with solutions are stored in it, so they are just a click away, then in an instant all legal questions are answered.

The industrial revolution 4.0 has changed the way people interact with the law. In the field of law, the notary profession will increasingly depend and require a lot of legal information engineers. We cannot go in the opposite direction to technological developments. Legal work is partially similar to how technology works so that legal work can be replaced by artificial intelligence machines. In this section, artificial intelligence machines will collaborate or work together with legal professionals. It is intended that the two intelligences between humans and artificial intelligence machines can be combined to achieve much better, faster, and more accurate results.

But not all legal work is as simple as the operation of machines. In legal cases in which there is a struggle between certainty, benefit and justice, artificial intelligence machines are able to guarantee legal certainty with a high degree of accuracy, but machines do not have the sensitivity to bring law closer to justice because justice cannot be measured scientifically.

\section{CONCLUSION}

Business actors need a guarantee of legal certainty, peace of law, speed and cost-effective to obtain the letter/deed and the necessary permits related to the type of company. The development of information technology and electronic transactions by using computers, computer networks, and/or electronic media does not eliminate the office and function of the Latin notary (Civil law) on the grounds that the jurisdiction that practices the authentication of instruments puts emphasis on preventive justice, avoiding litigation, the creation of speed and accuracy as well as maintenance of legal certainty as a public interest, can be justified 
economically. A notary is required to anticipate the challenge, turning it into an opportunity to strive. Some significant things in the framework of ease of effort in the 4.0 era: 1)That Cybernotary, in the case of a notary who performs the function of the Department and its authority can be assisted on the demands of acceleration of services ideas; 2)That transactions electronically by using the computer, computer network, and/or other electronic media must retain the main principle of the role of direct interacting with the citizens, providing a secure legal structure for the necessary transactions and supervision; 3)That the guarantee of legal certainty, legal peace, speed and cost-effective to obtain the letter/deed and the necessary permits related to the type of company for business actors is a challenge faced in order to be an opportunity in trying; 4)That any innovation that is part of a digital cycle is needed a conscious reflection to question whether a transaction without a trusted third-party assistance is really more of a guarantee of legal certainty and consumer protection; 5)That the role of notary (Latin) or civil law on the day in Indonesia is determined by legal politics and legal awareness in the determination of the legislator regarding the nature of the notary Office, the ordinance of making notarial deed and the characteristics of notarial deed.

\section{REFERENCES}

\section{A.M.Ramli, Kekuatan Akta Elektronik Sebagai Alat Bukti}

Pada Transaksi E-Commerce Dalam Sistem Hukum Indonesia, Media Notariat, April-Juni 2003, Tahun XVIII.

Adjie, Habib., Kebatalan dan Pembatalan Akta Notaris, Bandung: Refika Aditama, 2011.

Budiono, Herlien., Kumpulan Tulisan Hukum Perdata di Bidang Kenotariatan, Bandung: PT Citra Aditya Bakti, 2008.

Juwana, Hikmawanto., Tantangan Bagi Notaris Indonesia, Jakarta : Seminar Cyber Notary, (2011).

Kie, Tan Thong., Studi Notariat \& Serba Serbi Praktek Notaris, Jakarta: PT. Ichtiar Baru Van Hoeve, 2000.

Mansur, Dikdik M. Arief., Elisaris Gultom, Cyber Law dan Aspek Hukum Teknologi Informal, Bandung : Refika Aditama, 2015

Matra, Agung Fajar., Penerapan Cyber Notary di Indonesia Ditinjau dari Undang-Undang Nomor 30 Tahun 2004 tentang Jabatan Notaris, Depok : Tesis Magister Kenotariatan FH UI 2012

Suparni, Niniek., Cyberspace: Problematika dan Antisipasi Pengaturannya, Jakarta: Sinar Grafika, 2009.

Tedjosaputro, Liliana, Hukum Jabatan Notaris dan Relevansinya dalam Kehidupan Masyarakat, Semarang: CV.Agung, 2019.

Wibowo, Arimukti dkk, Kerangka Hukum Digital Signature dalam Elektronic Commerce, Jakarta : seminar Masyarakat Telekomunikasi Indonesia 
Pusat Ilmu Komputer,

Universitas Indonesia, 1999

Yulia, Aris., Profesi Notaris di Era

Industrialisasi

dalam

Perspektif Transendensi

Pancasila , Jurnal Law \&

Justice, Volume 4, Nomor 1, (2019)

Law No. 2 of 2014 Amendment to Law No. 30 of 2004 on Notary

Public

Law Number 11 Year 2008

concerning Information and

electronic transactions 